\title{
Covid-19 Salgını Sonrası Yiyecek ve Içecek Sektörü: Mutfak Şeflerinin Perspektiflerine Yönelik Bir Araştırma
}

\author{
Derya Demirdelen Alrawadieh ${ }^{1 * *}$ ibrahim Çifçi ${ }^{2}$ \\ 1 İstanbul Ayvansaray Üniversitesi, Plato Meslek Yüksekokulu, İstanbul, Türkiye, deryademirdelen@ayvansaray.edu.tr, ORCID: 0000-0002-7554-2256 \\ 2 İstanbul Üniversitesi, iktisat Fakültesi, Istanbul, Türkiye, ibrahim.cifci@istanbul.edu.tr, ORCID: 0000-0001-7469-1906
}

Öz

COVID-19 salgını yiyecek içecek sektörünü ciddi oranda etkilemiştir. Böylesine geniş çaplı bir salgının sektörü nasıl etkilediğini ortaya koymak oldukça önemli görülmektedir. Bu önemden hareketle araştırmanın amacı, COVID-19 salgını sırasında yiyecek-içecek sektörünün durumuna yönelik mutfak şeflerinin bakış açılarını belirlemek ve salgın sonrasındaki beklentileri ortaya koymaktır. Bu amaçla, toplamda 18 mutfak şefi ile görüşülmüştür. Elde edilen veriler içerik analizine tabi tutulmuş olup, sektörün durumuna yönelik mutfak şeflerinin bakış açıları iki başlık altında ele alınmıştır. Bunlar; COVID-19 salgını sırasında yiyecek-içecek sektörü (çalışanlar açısından algılar, değişen tüketici ihtiyaçları ve sektöre yönelik genel görüşler) ve COVID-19 salgını sonrasında yiyecek-içecek sektöründe ortaya çıkabilecek değişiklikler (yenilik uygulamaları, hijyen ve sanitasyon, robotik uygulamalar) olarak belirlenmiştir. Bu araştırma, COVID-19 salgını sırasında pandemiden fazlası ile etkilenmiş olan yiyecek ve içecek sektörüne yönelik sınırlı olan alan yazına teorik katkı sunmakta; aynı zamanda yiyecek içecek sektörüne, sektör paydaşlarına ve sektör çalışanlarına uygulamaya yönelik öneriler geliştirmektedir.

Anahtar Kelimeler: COVID-19 Pandemisi, Yiyecek ve İ̧ecek Sektörü, Mutfak Şeflerinin Perspektifleri

The Food and Beverage Sector in the Aftermath of the COVID-19: The Perspective of Chefs

\begin{abstract}
The COVID-19 pandemic has largely affected the food and beverage industry. It is important to understand how such a large-scale epidemic has affected the sector. In this vein, this paper aims to examine the perceptions of Turkish chefs about the potential impacts of the pandemic of the food and beverage industry during with focus on their expectations after the epidemic. For this purpose, a total of 18 chiefs were interviewed. The study examined the perceptions of Turkish chefs in two key directions: during COVID-19 (perceptions for employees, changing consumer needs and general views on the industry) and after COVID-19 (innovation practices, hygiene and sanitation, robotic applications). This research makes a theoretical contribution to the limited literature on the food and beverage industry the COVID-19 pandemic. The study also suggests practical implications for the food and beverage industry.
\end{abstract}

Keywords: COVID-19 Pandemic, Food and Beverage Industry, Chefs' Perspectives
Cilt 5, Sayı 2, 2021 ss. $439-454$

Gönderim : 29.05.2021

1. Düzeltme: 28.06 .2021

2. Düzeltme: 24.08 .2021

3. Düzeltme: 11.09 .2021

Kabul Tarihi: 14.09.2021

Research Article

Vol 5, No 2, 2021

pp. $439-454$

Received : 29.05.2021

Revision1: 28.06.2021

Revision2: 24.08 .2021

Revision3: 11.09.2021

Accepted: 14.09 .2021

\section{Önerilen Atıf/Suggested Citation}

Demirdelen Alrawadieh, D. ve Çifçi, í. (2021). Covid-19 Salgını Sonrası Yiyecek ve içcecek Sektörü: Mutfak Şeflerinin Perspektiflerine Yönelik Bir Araştırma. Güncel Turizm Araştırmaları Dergisi, 5(2), 439-454.

**Sorumlu yazar e-posta: deryademirdelen@ayvansaray.edu.tr 


\section{GíRiş}

COVID-19 pandemisi dünyada yakın tarihte daha önce görülmemiş bir sağlık krizine neden olmuştur. Birçok endüstri kolu, salgının bulaş riski nedeniyle üretime ani bir şekilde ara vermek zorunda kalmıştır. Tıpkı diğer endüstri dallarında olduğu gibi, turizm endüstrisi içerisinde yer alan yiyecek içecek işletmeleri de salgından ciddi oranda etkilenmiştir (Kim ve Lee, 2020; Okat vd. 2020; Chowdhury vd. 2020; Panzone vd. 2021; Bucak ve Yiğit, 2021). Birçok ülkede restoranlar, hükümetlerin pandemi sınırlama önlemleri nedeniyle kapanmaya, düşük hizmet kapasitesinde çalışmaya veya paket servis yöntemlerine yönelmeye mahkûm olmuştur. Hükümetlerin ortaya koyduğu kısıtlamalar normalleşme adımlarıyla yavaş yavaş gevşetilirken bile yiyecek içecek sektörü, tüketicilerin algıladığı risklerden, güven kaybından ve bulaş korkusundan zarar görmeye maalesef devam etmektedir (Dedeoğlu ve Boğan, 2021; Yost ve Cheng, 2021).

Salgın hem arz hem de talep açısından ciddi değişiklikleri beraberinde getirmiştir. Arz açısından, işletmelerin sürdürülebilirliğini tehdit etmiş (Okat vd. 2020), iş olanaklarını ve çalışma koşullarını zorlaştırmış (Bucak ve Yiğit, 2021) ve istihdamı azaltııştır (Goddard, 2021). Talep açısından ise tüketici algısı ve tüketim davranışlarında birtakım değişimlerin yaşanmasına neden olmuştur (Kim ve Lee, 2020; Bivona ve Cruz, 2021; Galanakis vd. 2021).

Alan yazındaki birçok çalışma COVID-19 salgını süresince yiyecek-içecek sektörünün ne şekilde etkilendiğini ortaya koymaktadır (Kim ve Lee, 2020). COVID-19 salgınının yiyecek içecek sektörüne etkileri ile ilgili alan yazının temelde üç olgu üzerinde şekillendiği görülmektedir. Bunlar; (i) tüketicilerin risk alg1sı (Örn. Byrd, 2021), (ii) restoranların uygulamaları ve izlediği stratejileri (Örn. Kim vd. 2021; Yang vd. 2021; Yost ve Cheng, 2021) ve (iii) farklı paydaşlarla (medya, müşteri ve çalışanlar) işbirlikçi stratejileri geliştirerek zorlu durumla başa çıkma çabaları (Örn. Bufquin vd. 2021; Sung ve King, 2021) şeklinde belirtilebilir. Ancak, salgın sonrasına ilişkin özelikle COVID19 pandemisinden fazlası ile etkilenmiş yiyecek ve içecek sektörüne yönelik araştırmalar hâlâ sınırlıdır (örn. Bucak ve Yiğit, 2021). Bu bağlamda mevcut çalışma, COVID-19 esnasında yiyecek-içecek sektörünün durumuna yönelik mutfak şeflerinin bakış açılarını belirlemek ve salgın sonrasında yiyecek-içecek sektörünün durumuna yönelik beklentiler ile ilgili ana temaları belirleyerek bu önemli konuya cevap vermektedir. Bu doğrultuda yiyecek-içecek sektöründe en önemli karakterlerden biri olan mutfak şeflerinin bakış açılarına başvurmak üzere nitel bir araştırma yürütülmüştür. Çalışmanın sonuçlarının ayrıca, COVID-19 salgını sonrası yiyecekiçecek sektöründe meydana gelebilecek zayıflık, tehdit, fırsat ve güçlü yönlerin ortaya konmasına katkı sağlayacağı öngörülmektedir.

\section{Alan Yazın Taraması}

2019 Aralık ortalarında Çin'de ortaya çıkan ve hızla tüm dünya ülkelerine yayılarak küresel bir salgına dönüşen COVID-19 (Gössling vd. 2020) nedeniyle 2020 yılının başlarında Dünya Sağlık Örgütü tarafından pandemi ilan edilmiştir (World Health Organization, 2020). Salgın ile beraber alınan sıkı önlemler; eğitim (Daniel, 2020), 
moda ve giyim (Brydges ve Hanlon, 2020), g1da üretimi (Hobbs, 2020) gibi birçok endüstriyi olumsuz yönde etkilemiştir. Bunların arasında turizm endüstrisi, esnek talep özelliği (Dedeoğlu ve Boğan, 2021) ve artan seyahat kısıtları gibi nedenlerle salgından en çok etkilenen endüstrilerin başında gelmektedir (Foo vd. 2020; Gursoy ve Chi, 2020; Demirdelen Alrawadieh, 2021). Salgının seyri ile birlikte konaklama işletmeleri (Hao vd. 2020; Lai ve Wong, 2020), havayolu işletmeleri (Abate vd. 2020), seyahat işletmeleri (İbiş, 2020) ve yeme-içme işletmeleri açısından ortaya çıkan yıkıcı etkiler (Chowdhury vd. 2020; Bucak ve Yiğit, 2021), sektördeki arz ve talep işleyişine zarar vermiştir.

Önceleri gerek dünyada gerekse Türkiye'de arz ve talep açısından turizm endüstrisinde görülen artış, salgın ile birlikte turist sayılarının ve turizm gelirlerinin azalmasına, turizm işletmelerinin kapanmasina ve bunun sonucunda turizm çalışanlarının da endüstriden uzaklaşmasına neden olmuştur. Örneğin, turizm sezonunun en yüksek olduğu temmuz ayı içerisinde Türkiye' de pandemiden önceki yıl olan 2019 yılı turizm geliri ile pandemi esnasında olan 2020 yılı aynı ay arasındaki değişim oranı -87,2 olarak belirtilmektedir (Kültür ve Turizm Bakanlığı, 2021).

Öte yandan, yiyecek ve içecek sektörü, insanlığın en temel ihtiyaçlarının karşılamasına kaynak oluşturan, ulusal ve uluslararası ekonomide hayati bir rol oynayan ve dünyada hızla büyüyen sektörlerden biri olmasına rağmen, COVID-19 pandemisinden ciddi ölçüde etkilenen iş alanlarının başında gelmektedir (Chowdhury vd. 2020). Her ne kadar yeme-içme ihtiyacı hiçbir zaman bitmese de var olan COVID19 krizi yiyecek içecek işletmelerinin kapasite kaybına uğramasına, darboğazların yaşanmasına ve bunun sonucunda sektörün ciddi ekonomik sorunlara sürüklenmesine neden olabilmektedir (Okat vd. 2020).

Salgının seyri ve salgın sonrasında geleceğe yönelik eğilimler konusunda yiyecekiçecek işletmelerine yönelik sınırlı bir alan yazın bulunmaktadır (Chowdhury vd. 2020; Panzone vd. 2021; Bucak ve Yiğit, 2021). Bu kapsamda COVID-19 salgınının yiyecekiçecek işletmeleri açısından etkilerini belirlemek ve salgın esnasında nasıl hayatta kaldıklarını ortaya koyabilmek önemli görünmektedir. Pandemi, yiyecek içecek işletmeciliğinin hayatta kalmasını ve geleceğini ciddi şekilde tehdit etmesine rağmen, işletmecilerden gelen yenilikler restoranların gelişmesine katkı bile sağlayabilir. Russell ve Faulkner (2004: 561) kaos ve karmaşıklık teorisine dayanarak, inovasyonun bireysel işletmeler tarafından öngörülmezlik anında keşfedilebileceğini belirtmişlerdir: "Kaosun ortasında bir boşluk bulun, bir fırsat yaratın ve statükoyu değiştirmeye, yeni standartları hayata geçirmeye başlayın". Örneğin, Okat ve arkadaşları (2020), yapmış oldukları çalışmada COVID-19 döneminde yiyecek-içecek işletmelerinin kaygılarının kendi sürdürülebilirlikleri olduğu sonucuna ulaşmışlardır.

Diğer bir yandan, Chowdhury ve arkadaşları (2020) çalışmalarında COVID-19 esnasında yiyecek içecek işletmelerinde kısa vadede etkilerin daha belirgin olduğunu savunurken (örn. işletme sermayesinin azalması); orta ve uzun vadede ise etkilerin daha karmaşık ve belirsiz olacağını belirtmiştir. Örneğin uzun vadede, kâr marjının düşmesi ve çalışan sayısının azaltılması olasılığı üzerinde durulmaktadır. Galanakis 
(2020) ise uzun vadede, pandeminin tüm g1da sektörünü dört ana alanda etkiyeceğini belirtmiştir. Bunlar; gıda güvenliği, biyoaktif gıda bileşenleri, g1da güvencesi ve sürdürülebilirlik olarak belirtilmiştir. Bucak ve Yiğit (2021), COVID-19 salgınının olası etkilerini ve salgın sonrası gelecek beklentilerini ortaya koymak amacıyla yiyecek içecek sektöründe yaptıkları çalışmada, salgının sektörü hem olumlu (örn. mesleğin öneminin artması), hem de olumsuz (örn. ekonomik daralma, iş olanaklarının ve çalışma koşullarının kötüleşmesi) yönde etkileyebileceğini belirtmiş ve salgın sonrasında yiyecek içecek sektöründe ortaya çıkabilecek değişikliklerin menü planlama, gıda güvenliği gibi konularda yaşanabileceğini belirtmiştir.

Dahası, salgın yiyecek içecek sektöründe çalışanları da etkilemiş ve motivasyon kaybına yol açmıştır (Bucak ve Yiğit, 2021). COVID-19 salgınından ciddi anlamda etkilenen tüm sektörlerde çalışanların mevcut kriz karşısında hayatta kalmak ve işlerini kaybetmemek adına bazı sorunlar yaşadığı yapılan çalışmalarda ortaya çıkmaktadır. Mevcut salgının, sektörde çalışanlar için iş kaybı, stres (Wong vd. 2021), kayg1, depresyon (Aguiar-Quintana vd. 2021), iş güvensizliği (Aguiar-Quintana vd. 2021; Vo-Thanh vd. 2021), mental yorgunluk (Vo-Thanh vd. 2021) gibi olumsuz durumları tetiklediği ve hatta turizm sektöründe çalışanların iyi oluşuna ciddi oranda zarar verdiği doğrulanmaktadır (Agarwal, 2021).

Salgının tüketici algısında değişiklikler ortaya koyduğu da açıtır (Bivona ve Cruz, 2021). Salgın, tüketicileri özellikle bağışıklık sistemini güçlendirmek maksatlı olarak sağlıklı, organik veya fonksiyonel gıdalara yöneltmiştir (Galanakis vd. 2021). Bunun yanı sıra, salgın sürecinde hükümetler tarafından alınan kapanma ve çeşitli kısıtlama kararları, tüketicilerin yeme-içme kültürünü de etkilemiştir (Gursoy ve Chi, 2020). Örneğin Kim ve Lee (2020), COVID-19 salgın tehdidini yüksek olarak algılayan tüketicilerin kalabalık ortamlarda bulunmaktan çekinecekleri ve bu doğrultuda özel odalı restoranları tercih edebileceğini belirtmektedir. Farklı çalışmalar ise, COVID-19 döneminde restoran tüketicisinin güvenini ve yemek yeme niyetleri üzerinde çevrimiçi yorumların (Luo ve Xu, 2021), ülkenin pozitif imajının (Wei, vd. 2021) ve müşteri sadakati ile şeffaflığın rolünü vurgulamaktadır (Yost ve Cheng, 2021). Aynı zamanda salgın nedeniyle, insanların evde yeme-içme olanaklarının artması (Bivona ve Cruz, 2021), sosyal mesafeden dolayı kapalı mekânlar yerine açık alanların tercih edilmesi ve paket servis usulüne yönelim vurgulanan önemli olgular arasındadır (Kim vd. 2021).

Öte yandan yiyecek içecek sektöründe robotların ve yapay zekânın kullanılmasının sektöre has bazı değişiklikleri de beraberinde getirmesi beklenmektedir (Cifci ve Demirdelen Alrawadieh, 2021). Özellikle salgın, yiyecek içecek işletmeleri açısından teknolojik eğilimlerin hızlanmasını tetiklemekte (Zeng vd. 2020; Demaitre, 2020; Seyitoğlu ve Ivanov, 2020; Özgüneş vd. 2020) ve salgın sonrasında yiyecek içecek işletmelerinde (mutfak veya servis alanları) sanal zekânın daha fazla kullanılması beklenmektedir (Özgüneş vd. 2020).

Sonuç olarak alan yazından hareketle, yiyecek içecek işletmeleri açısından yıkıcı etkisi olan COVID-19 salgınının mevcut etkilerinin belirlenmesi ve mevcut etkiler dışında 
gelecekte de sektörde bazı değişiklikleri beraberinde getirmesi beklenmektedir. $\mathrm{Bu}$ görüşten hareketle, araştırma kapsamında yiyecek içecek sektöründe mutfak şefi olarak çalışan bireylerin görüşlerine başvurulmuş ve güncel veya gelecekteki muhtemel bakış açıları ortaya konulmaya çalışılmıştır. Çalışmanın COVID-19 salgınıyla beraber ortaya çıkabilecek tehdit ve fırsatların belirlenmesi ve gerek teorik gerekse pratikte yazına katkı sağlaması beklenmektedir.

\section{YÖNTEM}

$\mathrm{Bu}$ araştırma, COVID-19 salgını sırasında yiyecek-içecek sektörünün durumuna yönelik mutfak şeflerinin bakış açılarını belirlemeyi ve salgın sonrasındaki beklentileri ortaya koymayı amaçlamaktadır. Araştırmada nitel yaklaşım benimsenmiş olup, yiyecek-içecek sektöründe yer alan mutfak şefleriyle yarı yapılandırılmış derinlemesine görüşmeler yapılmıştır. Araştırmanın evreni Türkiye'de yiyecek içecek sektöründeki mutfak şeflerinden oluşmaktadır. Mutfak şefleri, yiyecek içecek sektörünün en önemli paydaşlarından biri olarak kabul edilmektedir (Demirkol ve Çifçi, 2020).

Evren içerisinden örneklem seçilirken öncelikle kolayda örneklem yöntemine başvurulmuş olup, yeterli veri doygunluğuna ulaşılamadığından veri toplama süreci kartopu örneklem ile tamamlanmıştır. Bu iki aşamalı örneklem stratejisinin benimsenmesindeki neden, söz konusu katılımcılara ulaşma zorluğundan kaynaklanmaktadır. Veri toplama süreci sonunda toplamda 18 mutfak şefiyle görüşme tamamlanmıştır. Nitel araştırmalarda veri doygunluğuna ulaşmak veri toplama sürecini tamamlamak için önemli bir ölçüt olarak görülmekte ve veri doygunluğundan sonra veri toplamanın gerekli olmadı̆̆ı kabul görmektedir (Van Manen vd., 2016; Saunders vd., 2018). Bir diğer ifadeyle "veri doygunluğuna ulaşılmaması araştırmanın kalitesini etkilemekte ve içerik geçerliliğini engellemektedir" (Fusch ve Ness, 2015: 1408). Dolayısıyla bu çalışmada, verilerin birbirini tekrar etmesi ve yeterli doygunluğa ulaşılması sebebiyle katılımcı sayısı yeterli olarak görülmektedir (Glaser ve Strauss, 1967; Saunders vd., 2018). Araştırmada, veri doygunluğunun yanı sıra veri derinliği ve kalitesi de göz önünde tutulmuştur (Van Manen, 2016).

Görüşmeler, Şubat-Mart 2021 tarihleri arasında yaklaşık dört haftalık bir süreyi kapsamaktadır. Bu kapsamda öncelikle şeflere e-posta veya mesaj yoluyla ulaşılarak görüşme zamanı konusunda ortak bir görüşe varılmıştır. COVID-19 salgınının yoğun olduğu bu dönemde kısıtlı hareketlilik ve sosyal mesafe gibi nedenlerle tüm görüşmeler telefon aracılığıyla gerçekleştirilmiş olup, yapılan görüşmeler şeflerden alınan izinle birlikte kayıt altına alınmıştır. Görüşmeler ortalama 30 dakika sürmüş olup, süreç sonunda 102 sayfa ve yaklaşık 36400 kelime içeren bir dosya elde edilmiştir.

Mutfak şeflerinin COVID-19 salgını sırasında ve sonrasında yiyecek-içecek sektörünün şimdiki durumuna ve geleceğine yönelik bakış açılarını belirlemeye yönelik oluşturulan sorular geniş bir alan yazın taramasına dayanılarak oluşturulmuştur. Öncelikle COVID-19 salgını sırasında yiyecek içecek sektörüne 
yönelik alan yazın sınırlı olduğundan (Chowdhury vd. 2020; Kim ve Lee, 2020; Okat vd. 2020; Özgüneş vd. 2020), soruların oluşturulması esnasında turizm endüstrisi ile ilgili araştırmalar da bu taramaya dâhil edilmiştir (Hao vd. 2020; Foo vd. 2020; Lai ve Wong, 2020; Gursoy ve Chi, 2020; Gössling vd. 2020). Alan yazın ve araştırmacıların görüşleri doğrultusunda hazırlanan sorular, iki akademisyene gönderilmiş ve görüşleri alınmıştır. Söz konusu akademisyenlerin turizm alanında nitel araştırmalar üzerine birçok ulusal ve uluslararası yayını bulunmaktadır. Alınan uzman görüşleri sonucunda, soruların anlaşılırlığ1 ve kapsamı üzerinde görüş birliğine varılmıştır.

Görüşme sorularının birinci kısmında yaş, medeni durum, eğitim ve çalışma deneyimi gibi demografik bilgiler bulunurken; ikinci kısmında öncelikle COVID-19 salgınının yiyecek-içecek sektörünü nasıl etkilediği sorulmuştur. Sonrasında ise katılımcılara COVID-19 salgınıyla beraber yiyecek içecek sektöründe yaşanabilecek değişimlere ve bu değişimlerin sonuçlarına yönelik açık uçlu sorular yöneltilmiştir. Bu yöntem sayesinde mutfak şeflerinden derinlemesine bilgi elde edilmesi sağlanmıştır. Son olarak araştırmada içerik analizi uygulanmıştır. İçerik analizinin güvenirliği için veriler, Lune ve Berg'in (2004) önerdiği şekilde iki araştırmacı tarafından ayrı ayrı kodlanmış olup (tümevarım ve tümdengelime dayalı karma bir bakış açısı doğrultusunda), elde edilen temalar üzerinde uzlaşılmıştır. Alan yazında birçok araştırmada bu yöntem güvenirlik için kullanılmaktadır (örn. Alrawadieh ve Law 2019; Bucak ve Yiğit, 2021). Oluşturulan son çerçeve ile mutfak şeflerinin bakış açılarına yönelik temalar iki başlık altında (salgın esnası ve sonrasına yönelik) sunulmuştur. Bulguların sunulmasında verilerin özgünlüğüne bağlı kalınarak doğrudan alıntılardan da yararlanılmıştır (Elo ve Kyngäs, 2008). Bu araştırma kapsamında etik onay İstanbul Üniversitesi Sosyal ve Beşerî Bilimler Araştırmaları Etik Kurulu Başkanlığı'ndan (2021/30) alınmıştır.

\section{BULGULAR}

COVID-19 sonrası yiyecek-içecek sektörünün durumuna yönelik mutfak şeflerinin bakış açılarını ortaya koyan bu araştırmadan elde edilen demografik bulgular aşağ1daki tabloda gösterilmektedir. Tablo 1'de gösterildiği gibi şeflerin çoğunluğu 4149 yaş grubunda yer alırken, yine çoğunluğu evlidir. Lisansüstü eğitime sahip şeflerin sayısı az iken, büyük çoğunluğu lise ve öncesi eğitim görmüştür. Şeflerin hepsinin sektör deneyimi oldukça yüksektir. Nitekim tabloda gösterildiği gibi en az deneyime sahip olan dahi, 15 yıldır bu sektörde çalışmaktadır. Son olarak, görüşülen şeflerin hepsi erkek olduğundan tabloda cinsiyete yönelik bir ifadeye yer verilmemiştir.

Tablo 1. Şeflere yönelik demografik bulgular

\begin{tabular}{llll}
\hline Yaş & & Ĕ̆itim & \\
\hline 35 ve altı & 4 & Lise ve öncesi & 8 \\
\hline $36-40$ & 4 & Önlisans/ Lisans & 3 \\
\hline $41-49$ & 8 & Lisansüstü & \\
\hline $50+$ & 2 & Çalışma Deneyimi & 5 \\
\hline Medeni Durum & & $15-19$ yıl &
\end{tabular}




\begin{tabular}{llll}
\hline Evli & 15 & $20-29$ yıl & 7 \\
\hline Bekar & 3 & 30 ylldan fazla & 6 \\
\hline
\end{tabular}

Yapılan içerik analizine göre, COVID-19 küresel salgını ile birlikte yiyecek-içecek sektörünün durumu iki başlık altında incelenmiştir. Bunlar; COVID-19 salgını sırasında yiyecek-içecek sektörü (temalar; çalışanlar açısından algılar, değişen tüketici ihtiyaçları ve sektöre yönelik genel görüşler) ve COVID-19 salgını sonrasında yiyecekiçecek sektöründe ortaya çıkabilecek değişiklikler (temalar; yenilik uygulamaları, hijyen ve sanitasyon, robotik uygulamalar) olarak belirlenmiş ve aşağıdaki başlıklarda detaylandırılmıştır.

\section{COVID-19 Salgını Sırasında Yiyecek-İçecek Sektörü}

Alan yazında birçok çalışmada COVID-19 salgınının yiyecek-içecek sektörünü ve bu alanda çalışanları ciddi oranda etkilediği belirtilmektedir (Örn. Bucak ve Yiğit, 2021). Bu sonuçtan hareketle, söz konusu araştırmada öncelikle katılımcılara mevcut salgının yiyecek-içecek sektöründe çalışanları nasıl etkilediği yönünde görüşleri sorulmuştur. $\mathrm{Bu}$ kapsamda hemen hemen tüm katılımcılar mali kayıp konusundaki sıkıntılarını belirtirken, sonrasında moral ve motivasyon düşüklüğü, kaygı, stres, depresyon gibi sorunları belirtmişlerdir. Dolayısıyla bu kapsamda ortaya çıkan ilk tema, çalışanlar açısından ortaya çıkan algılardır. Örneğin, bu süreçte birçok işletmenin kapalı olduğunu belirten K3 görüşünü şu sözlerle ifade etmiştir:

"Elimizdekileri kaybedecek miyiz korkusu hala devam ediyor, ilk günden beri devam ediyor. Personelimiz için de aynı şekilde. Uzun zamandır birlikte çalıştı̆̆ımız bir ekip var... Bu arkadaşların hakkını nasıl sağlayacağız diye bir endişe yaşıyoruz açıkçası..."

Birçok sektör gibi yeme-içme işlemeleri de mevcut pandemiden ciddi oranda etkilenmektedir (Chowdhury vd. 2020). Dolayısıyla bu etki, bu sektörde kariyer hayatına devam eden çalışanlar veya bu alanda ilerleyen zamanlarda çalışacak olanlar açısından da birtakım değişiklikleri beraberinde getirebilir. Her ne kadar yeme-içme ihtiyacı hiçbir zaman bitmese de özellikle COVID-19 gibi kriz ortamlarında turizm sektöründe çalışanların veya çalışacak olanların geleceğe yönelik kaygı duyması beklenen bir durumdur (Aguiar-Quintana vd., 2021; Demirdelen Alrawadieh, 2021). Bu kapsamda K3 görüşünü şu sözlerle belirtmiştir:

"Stajyerler ve öğrenciler daha endişeliler, yani 'iş bulabilecek miyiz' noktasında kaygıları var... Kendi çalışanlarımızdan da 15 çalışanımız vardı, bugün maalesef 6 tanesi çalışıyor. Geri kalan 9 personelimiz de devletin verdiği ödeneklerden faydalanmaya devam ediyorlar. Onlar da endişeyle bekliyorlar bize ne olacak diye... Herkeste bir endişe, herkeste bir tedirginlik var açıç̧ası..."

COVID-19 salgını sırasında yiyecek-içecek sektörü açısından ortaya konulan bir diğer tema, değişen tüketici ihtiyaçlarıdır. Mutfak şeflerin persfektiflerinden hareketle, tüketiciler, daha hızlı ve pratik yemekleri tercih etmeye başlamış, hijyen konusuna odaklanmış, daha temizdir düşüncesi ile talep zincir ve tanınan yeme-içme işletmelerine doğru yönelmiş, doğal ürün/yemek tercihleri artış göstermiş ve dişarıda yemek yeme tercihleri değişerek onun yerine eve servis hizmetleri artış göstermiştir. 
Benzer şekilde Bivona ve Cruz (2021) araştırmasında, COVID-19 ile birlikte tüketicilerin tercihlerinde ve davranışlarında birçok değişikliğin ortaya çıktığını (örn. tüketimin dışarıda yemek yeme alışkanlığından ziyade eve teslim yemek hizmetlerine doğru yönelmesi) belirtmiştir. Bu kapsamda K1 ve K9 görüşlerini şu sözlerle belirtmiştir:

“...Yemek yemek bir tek insanın karnını doyurması demek değil. Aynı zamanda sosyal bir paylaşım. Salgından sonra bu sosyal paylaşımın olmaması ile insanların yemek seçimleri daha hızl ve daha pratik seçimler oldu, ama tabii ki yine lezzetli ve maksimum güvendikleri lokasyonlardan sipariş ettiler..." K1

"Şimdi dışarda yeme oranının giderek azaldığını görüyoruz sağlıklı bir eğilime yönelimin daha ă̆ırlıkl olduğunu görüyoruz. Mesela bizim işletmemiz açısından baktığınız zaman bize gelen taleplerin de bu yöne kaydığını görüyoruz..." K9

Aynı zamanda pandemi ile birlikte tüketiciler teknolojinin imkânlarından daha fazla yararlanmaya başlamıştır. Bu kapsamda K18 görüşünü şu sözlerle belirtmiştir: “... Online hizmetler artıyor, insanlar çok daha hızlı bir şekilde yiyeceğe ulaşmak için akıllı telefonlar, tabletler, bilgisayarlar kullanabiliyor...". Bu bulgu, ilerleyen temada anlatılacağı gibi sektör açısından da birtakım değişiklikleri beraberinde getirmiştir.

COVID-19 salgını sırasında yiyecek-içecek sektörüne yönelik ortaya çıkan son tema ise, sektöre yönelik genel görüşlerdir. $\mathrm{Bu}$ kapsamda işyeri kapatma, işten çıkma/çıkarma gibi olumsuz görüşler olduğu gibi; krizi firsata çevirme gibi olumlu görüşler de mevcuttur. Bucak ve Yiğit (2021) de benzer şekilde çalışmasında COVID19 salgını ile birlikte yiyecek-içecek sektöründe yer alan şeflerin bakış açılarını sunarken optimist (iyimser) ve pesimist (kötümser) bakış açılarının var olduğunu belirtmiştir.

"İşletmeler niçin vardır, işletmeler para kazanmak ve kâr etmek için vardır. Dolayısıyla işletmeler bu krizde borç batağından çıkacaklar ve borç bată̆ından çıktıktan sonra da yeni kurallarla hizmet vermeye başlayacaklar... Şimdi açıldık diyelim. Ne yapacaksın, küçülmeye gideceksin... Personelin sayısın azaltacaksın, ürünleri azaltacaksın... Daha hizlı ve daha az personelle servis edebileceğin ama daha fazla kâr edebileceğin ürünler üzerine çalışacaksın, bu da kaliteyi düşürecek..." K8

“...Ben hemen bu krizi firsata çevirebilmek adına kendim 'Exclusive Catering Şirketi' kurdum. Yani önceden insanlar size geliyorlard, şimdi artık biz belirli şartlar ve kurallarla insanlara gidip hizmet vermeye gayret gösteriyoruz yiyecek içecek sektörü olarak..." K9

\section{COVID-19 Salgını Sonrasında Yiyecek-İçecek Sektöründe Ortaya Çıkabilecek Değişiklikler}

COVID-19 salgınının diğer birçok sektörde olduğu gibi yiyecek-içecek işletmeleri açısından da birtakım değişiklikleri getireceği beklenmektedir (Bucak ve Yiğit, 2021). $\mathrm{Bu}$ kapsamda, araştırmadan elde edilen bulgular neticesinde restoran işletmelerinin daha fazla yenilik çalışmalarına yönelmesi, hijyen ve sanitasyon açısından ekstra özen 
ve önem gösterilmesi ve hatta sektörde robotlaşmanın yaygınlaşması beklentiler arasindadir.

Öncelikle mutfak şeflerinin bakış açlarından hareketle yiyecek içecek işletmelerinde yenilik uygulamaları hızla artmaktadır. Özellikle bu kriz döneminde hayatta kalmak isteyen restoranlar, üründe veya süreçte birtakım yenilikler planlamışlardır. Önceleri bu derece yaygın değilken (Cankül, 2019), pandemi ile birlikte 'gel-al' servisleri, temassiz ödeme, paket servis, QR kodlar, dijital menüler ve sonucunda otomasyon kullanımı yüksek oranda artmıştır. Hatta yiyecek içecek işletmeleri açısından bu hızlı değişimin mevcut pandemi ile birlikte ilerleyen zamanlarda daha yaygın olması beklenmektedir.

Bu kapsamda gerek yiyecek içecek işletmeleri gerekse de tüketiciler teknolojiden daha fazla yararlanmaya başlamıştır. Zeten Zeng ve arkadaşlarının (2020) yapmış olduğu çalışmada, turizm endüstrisinde günümüzde işletmeler salgının getirmiş olduğu zorlu depresyonla başa çıkacak çözümleri fazlasıyla teknolojik gelişmelere adapte olmakta aramaktadır. Bu temaya yönelik aşağıdaki örnekler verilmiştir:

"Bu pandemi süreci ile işte QR kodla okuma ve dijital menü sistemine anında geçmek zorunda kaldık... Biz kendi işletmemiz açısından düşünürsek teknolojiye inanılmaz hızlı adapte olmaya gayret gösteriyoruz. Çünkü çok fazla faydasını görüyoruz..." K9

“...Hedeflerim çok farklıydı, çok farklı alanlara yöneldim... Sonra paket servise başladık..." K7

Çalışmadan elde edilen bulgulara göre ortaya çıan bir diğer tema, hijyen ve sanitasyon açısından gelişmiş önlemlerinin alınması ve gıda güvenliği konusuna özen gösterilmesidir. Bu kapsamda, katılımcılara pandemiden sonra her şeyin normalde dönüp dönmeyeceği yönünde sorular sorulmuştur. Katılımcıların büyük kısmı her şeyin eskisi gibi olacağını belirtirse de aynı zamanda büyük oranda kaygılarını da dile getirmişlerdir. Bu kapsamda K8 görüşünü şu sözlerle belirtmiştir:

“...Insanlar çok fazla dikkat etmiyordu... Bu pandemi döneminden sonra bir insan bir yerde yiyip içeceği zaman öncelikli diyecek 'ben buraya oturacağım da bakayım nasıl bir yer, sıkışık mi, masalar temiz mi, sandalye aralarında gerekli mesafeler var mı' diye düşünecek... İçeri girdiğgi zaman; ocă̆ıl, tezgâhı, yemeğgin çıktı̆̆ı yeri görmek isteyecek..."

Son olarak, katılımcılara pandemi ile birlikte robotlaşmanın yaygın kullanımına yönelik sorular yöneltilmiştir. Katılımcılar pandemi ile birlikte yapay zeka ve robotların yiyecek-içecek sektöründe daha fazla kabul göreceğine yönelik ağırlıklı olarak görüş bildirse de, sektörel ve kültürel açıdan robotlaşmanın uygun olmadığı yönünde de görüşler mevcuttur. Bu kapsamda K12 görüşünü şu şekilde belirtmektedir:

“...Temas olmadığı için günümüzde düşünebiliriz. İnsana değmeden ne biliyim daha sosyal mesafeli olarak robotlar bu işi yapabilir mi evet yapabilir..." 
Özellikle gıda üretiminin yapıldığı işletmelerde salgının bulaş riskini önlemek amacıyla gıda güvenliği açısından robotik uygulamalar hızla kabul görmüştür (Blit, 2020). Örneğin, salgın sürecinde işletmeler gıda ve malzeme tedarikinde çalışanlarının sağlığını riske atmadan, fiziksel mesafe kurallarına uygun bir biçimde hijyen ve sanitasyon uygulamalarını teknolojik uygulamalar (UV dezenfeksiyonu, ozon cihazları, temassız ödeme) desteğiyle sağlamıştır (Demaitre, 2020; Seyitoğlu ve Ivanov, 2020). Bu süreç, öteden beri süre gelen insan eli değmeden (Wilson, 2010) gida işletmeciliği uygulamalarının daha fazla kabul görme olasılığını da destekleyecektir. Benzer şekilde Özgüneş ve arkadaşları (2020), özellikle salgın sonrası süreçte restoranlarda sanal zekâ ve robotların yaygın kullanacağını belirtmiştir.

\section{SONUÇ, TARTIŞMA VE ÖNERİLER}

$\mathrm{Bu}$ araştırma, COVID-19 salgını sırasında yiyecek-içecek sektörünün durumunu ve salgın sonrasındaki beklentileri ve değişimleri belirlemek amacıyla hazırlanmıştır. Görüşmeden elde edilen veriler içerik analizi ile çözümlenmiş olup, iki başlık altında sunulmuştur. Bunlar; yiyecek içecek sektöründe çalışanlar, salgın esnasında değişen tüketici ihtiyaçları ve sektöre yönelik genel görüşler doğrultusunda salgın sırasında yiyecek-içecek sektörünün yapısını ortaya koyarken; sektörde yaşanabilecek yenilenmeler, hijyen ve sanitasyon ve robotlaşmanın yaygınlaşması ise salgın sonrasında yiyecek-içecek sektöründe ortaya çıkabilecek değişiklikler olarak belirlenmiştir. Araştırmadan elde edilen bulgular, COVID-19 salgını esnasında yiyecek-içecek sektörünün salgın ile nasıl başa çıkmaya çalıştığını ve salgından sonraki dönemlerde sektörel eğilimlerin ne yönde olacağını göstermek açısından değerlidir.

Öncelikle, COVID-19, yiyecek içecek sektöründe çalışanlar için bir takım endişe ve tehditleri beraberinde getirmektedir. Yapılan görüşmeler neticesinde yiyecek içecek sektöründe çalışanların salgından kaynaklı gerek maddi gerekse manevi sorunlar yaşadığı ortaya konulmuştur. Bu kapsamda pandemi koşullarında işletmelerin varlığını devam ettirmek, kar elde etmek veya sürdürülebilirliğini sağlamak amacıyla teşviklerden tam fayda elde edilmesi sağlanmalıdır. Dahası, özellikle politika yapıcıların COVID-19 döneminde çalışanların kaygılarını anlamaya yönelik uygulamaları hayata geçirmesi ve onları desteklemesi gerekmektedir. Özellikle Türkiye'de COVID-19 sürecinde işten çıkarmaların yasaklanması, çalışanların kısa çalışma ödeneğinden faydalanması (İşkur, 2021) ve COVID-19 devam ettiği sürece kısa çalışma ödeneğinin uzatılması (Resmî Gazete, 2020) gibi devlet uygulamaları buna örnek gösterilse de istihdamı koruyucu tedbirlerin alınması (Balci ve Çetin, 2020) ve bu desteklerin arttırılması önerilmektedir.

Bir diğer bulgudan hareketle, değişen koşullara ve tüketici ihtiyaçlarına yönelik ürün/hizmet anlayışı sunmak zorlu koşullarda dahi oldukça önemli görülmektedir. $\mathrm{Bu}$ kapsamda tüketici beklentileri doğrultudunda hijyen kurallarına uygun davranılmalı, temiz işletme algısı ve vurgusu ön plana çıkarılmalıdır. Örneğin; Güvenli Turizm ve Güvenli Gıda gibi kavramlarla sektör desteklenebilir. Unutulmamalıdır ki, 
talebin koşullarını iyi analiz etmek ve talebe uygun arz imkanları geliştirmek kriz ortamında dahi fırsatların oluşmasını sağlayabilir.

Mutfak şeflerinin COVID-19 salgını sonrasına yönelik görüşleri de bulunmaktadır. Bu kapsamda en önemli bulgulardan bir tanesi işletmelerin yenilenmesidir. Günümüz dahil, gelecekte de değişen koşullara uyum sağlayan ve açık sistem anlayışını benimseyen işletmelerin varlığını devam ettirmesi tesadüf değildir. Dolayısıyla ürün ve/veya hizmet anlaşında, işletme kültüründe ve süreçte çağın gerektirdiği koşulları benimsemek önemli görülmektedir. Örneğin, mevcut pandemi temassız ödemenin yaygınlaşmasını sağlamıştır, dolayısıyla işletmeler yenilikleri takip etmeli ve bu uygulamaları hayata geçirmelidir.

Benzer şekilde, mevcut kriz ortamında hayatta kalmak için teknolojinin imkanlarından daha fazla faydalanılması önerilmektedir. Bu kapsamda hayatta kalmak isteyen, sürdürülebilirliğini korumak ve kar elde etmek isteyen yiyecek içecek işletmelerinin rekabet avantajı elde edebilmesi için proaktif politikalar yürütmesi ve gelişmelere adapte olması beklenmektedir. Özellikle mevcut koşullar paket servis, online sipariş gibi hizmetlerin artmasını sağladığından, bu uygulamaların yaygınlaştırılması ile birlikte var olan kriz ortamından başarı ile çıkılması hedeflenmelidir. Salgın son bulsa dahi, teknoloji ile birlikte hayatı kolaylaştıran uygulamaların değişmeyeceği açıktır.

Son olarak, salgının robotlaşmayı hızlandırması beklentiler arasındadır. Özellikle fiziksel mesafe kuralları baz alındığında; üretimde, sunumda ve dağıtımda yapay zekanın ve robotların kullanılması artış gösterebilir. Bu kapsamda robotların yaygın kullanımı işgücü piyasasını değiştirebileceği gibi işsizlik oranını da arttırabilir (Cifci ve Demirdelen Alrawadieh, 2021). Dolayısıyla mevcut salgın son bulsa dahi, yiyecek içecek işletmelerinin ve bu sektörde çalışanların kısa, orta ve uzun vadeli planlar yapması, aynı zamanda mesleki gelişmeleri de takip etmeleri önerilmektedir.

Sonuç olarak, elde edilen bulguların alan yazına teorik katkı sunması ve yiyecek içecek sektörüne, sektördeki paydaşlara ve sektör çalışanlarına uygulamaya yönelik katkı sağlaması beklenmektedir. Ancak her araştırmada olduğu gibi mevcut araştırmanın da bazı kısıtları bulunmaktadır. Öncelikle, yiyecek içecek sektörünün güncel durumuna ve gelecekteki eğilimleri ortaya koyabilmek adına mutfak şeflerinin görüşlerine başvurulmuştur. Bu değerlendirmenin sektörde yer alan tüm paydaşlar açısından yapılması ve bulguların gerek nitel gerekse nicel açıdan değerlendirilmesi önemli görülmektedir. Yiyecek-içecek sektöründe yer alan diğer paydaşların (işletme sahipleri, işletme yöneticileri) görüşlerine başvurmak daha kapsamlı bulguların ortaya konulması açısından oldukça değerli ve önemlidir. Elde edilen bulgulardan yola çıkarak, mutfak şefleri değişen tüketici anlayışı ve ihtiyaçlarını belirtse de tüketiciler gözünden benzer bir çalışmanın yapılması daha şeffaf ve geçerli bilgilerin toplanması açısından önem arz etmektedir. Dahası, elde edilen bulguların COVID-19 esnasında toplanmış olması, mutfak şeflerinin bakış açılarının ve gelecek beklentilerinin daha karamsar bir şekilde sunulmasına sebep olmuş olabilir. Özellikle mevcut pandeminin ne zaman son bulacağının bilinmemesi ve ne zaman normal 
hayata geçileceği konusundaki karamsar bakış açısı, bulguları da etkilemiş olabilir. Çünkü özellikle iş kaygısı, kâr elde edememe, kapanma gibi ifade edilen pek çok görüş, COVID-19 pandemisinden yüksek oranda etkilenen yiyecek içecek mutfak şeflerinden toplanmıştır. COVID-19 salgını sonrası çalışmanın tekrarlanması ve mevcut farklılıkların gözetilmesi önemli görülmektedir. Dahası, önümüzdeki çalışmalarda nicel veya inovatif yaklaşımlar kullanılarak araştırmanın geçerliliği teyit edilebilir.

Hakem Değerlendirmesi: Dış bağımsız.

Teşekkür: Katkılarından dolayı hakemlere teşekkür ederiz.

Destek Bilgisi: Herhangi bir kurum ve/veya kuruluştan destek alınmamıştır.

Çıkar Çatışması: Yazarlar arasında çıkar çatışması yoktur.

Etik Onayı: Bu çalışmanın tüm hazırlanma süreçlerinde etik kurallara riayet edildiğini yazar(lar) beyan eder. Aksi bir durumun tespiti halinde Güncel Turizm Araştırmaları
Dergisi'nin hiçbir sorumluluğu olmayıp, tüm sorumluluk makale yazar(lar)ına aittir.

Bilgilendirilmiş Onam Formu: Tüm taraflar kendi rızaları ile çalışmaya dâhil olmuşlardır.

Etik Kurul Onayı: İstanbul Üniversitesi Sosyal ve Beşerî Bilimler Araştırmaları Etik Kurulu Başkanlığ 08.02.2021 tarih ve 02 sayılı toplantısı ile izin alınmıştır.

Araştırmacıların Katkı Oranı: Yazarlar çalışmaya eşit oranda katkı sağlamıştır.

Veri Kullanılabilirlik Beyanı: Araştırma verileri paylaşılmamıştır.

\section{KAYNAKÇA}

Abate, M., Christidis, P. ve Purwanto, A. J. (2020). Government support to airlines in the aftermath of the COVID-19 pandemic. Journal of Air Transport Management, 89, 101931.

Agarwal, P. (2021). Shattered but smiling: Human resource management and the wellbeing of hotel employees during COVID-19. International Journal of Hospitality Management, $93,102765$.

Aguiar-Quintana, T., Nguyen, H., Araujo-Cabrera, Y. ve Sanabria-Díaz, J. M. (2021). Do job insecurity, anxiety and depression caused by the COVID-19 pandemic influence hotel employees' self-rated task performance? The moderating role of employee resilience. International Journal of Hospitality Management, 94, 102868.

Alrawadieh, Z. ve Law, R. (2019). Determinants of hotel guests' satisfaction from the perspective of online hotel reviewers. International Journal of Culture, Tourism and Hospitality Research, 13(1), 84-97.

Balci, Y. ve Çetin, G. (2020). Covid-19 pandemi sürecinin Türkiye'de istihdama etkileri ve kamu açısından alınması gereken tedbirler. İstanbul Ticaret Üniversitesi Sosyal Bilimler Dergisi, 19(37), 40-58.

Bivona, E. ve Cruz, M. (2021). Can business model innovation help SMEs in the food and beverage industry to respond to crises? Findings from a Swiss brewery during COVID19. British Food Journal. Doi: 10.1108/BFJ-07-2020-0643

Blit, J. (2020). Automation and Reallocation: Will COVID-19 usher in the future of work?, Canadian Public Policy, 46(2), 192-202. 
Bufquin, D., Park, J. Y., Back, R. M., de Souza Meira, J. V. ve Hight, S. K. (2021). Employee work status, mental health, substance use, and career turnover intentions: An examination of restaurant employees during COVID-19. International Journal of Hospitality Management, 93, 102764.

Brydges, T. ve Hanlon, M. (2020). Garment worker rights and the fashion industry's response to COVID-19. Dialogues in Human Geography, 10(2), 195-198.

Byrd, K. Her, E. Fan, A. Almanza, B. Liu, Y. \& Leitch, S. (2021). Restaurants and COVID-19: What are consumers' risk perceptions about restaurant food and its packaging during the pandemic?, International Journal of Hospitality Management, 94, 102821.

Bucak, T. ve Yiğit, S. (2021). The future of the chef occupation and the food and beverage sector after the COVID-19 outbreak: Opinions of Turkish chefs. International Journal of Hospitality Management, 92, 102682.

Cankül, D. (2019). İşletmelerde yenilik uygulamaları: Restoran işletmeleri örneği. Gastroia: Journal of Gastronomy and Travel Research, 3(2), 225-240.

Chowdhury, M. T., Sarkar, A., Paul, S. K. ve Moktadir, M. A. (2020). A case study on strategies to deal with the impacts of COVID-19 pandemic in the food and beverage industry. Operations Management Research, Doi: 10.1007/s12063-020-00166-9.

Çifçi, İ. ve Demirdelen Alrawadieh, D. (2021-yayın aşamasında). Predicting the Future of the Foodservice Industry: A Robot-Based Economy Perspective. Ivanov S. \& C. Webster (Ed.), içinde Future Tourism in A Robot-Based Economy, Bristol, UK: Channel View Publications.

Daniel, J. (2020). Education and the COVID-19 pandemic. Prospects, 49(1), 91-96.

Dedeoğlu, B. B. ve Boğan, E. (2021). The motivations of visiting upscale restaurants during the COVID-19 pandemic: The role of risk perception and trust in government. International Journal of Hospitality Management, 95, 102905.

Demaitre, E. (2020). COVID-19 pandemic prompts more robot usage worldwide. [URL: https://www.therobotreport.com/covid-19-pandemic-prompts-more-robot-usage] (Erişim Tarihi: 18 Mayıs 2021).

Demirdelen Alrawadieh, D. (2021-yayın aşamasında). Mapping the Governmental Response to Covid-19 Pandemic And its Implications on the Hospitality and Tourism Industry: The Case of Turkey. Nunkoo, R., D. Gürsoy, M., Sarış̧ık \& E. Boğan (Ed.), içinde Covid19 Pandemic And The Hospitality And Tourism Industry, What is Next?, Edward Elgar publishers.

Demirdelen Alrawadieh, D. (2021). Does employability anxiety trigger psychological distress and academic major dissatisfaction? A study on tour guiding students. Journal of Tourismology, 7(1), 55-72.

Demirkol, Ş. ve Çifçi, İ. (2020). Delving into the Role of Celebrity Chefs and Gourmets in Culinary Destination Marketing. European Journal of Tourism Research, 26, 1-31.

Elo, S. ve Kyngäs, H. (2008). The qualitative content analysis process. Journal of Advanced Nursing, 62(1), 107-115.

Foo, L. P., Chin, M. Y., Tan, K. L. ve Phuah, K. T. (2020). The impact of COVID-19 on tourism industry in Malaysia. Current Issues in Tourism, Doi: 10.1080/13683500.2020.1777951 
Fusch, P. I. ve Ness, L. R. (2015). Are we there yet? Data saturation in qualitative research. The qualitative report, 20(9), 1408.

Galanakis, C. M., Rizou, M., Aldawoud, T. M., Ucak, I. ve Rowan, N. J. (2021). Innovations and technology disruptions in the food sector within the COVID-19 pandemic and postlockdown era. Trends in Food Science \& Technology, 110, 193-200.

Galanakis, C. M. (2020). The food systems in the era of the coronavirus (COVID-19) pandemic crisis. Foods, 9(4). https://doi.org/10.3390/foods9040523.

Glaser, B. G. ve Strauss, A.L. (1967). The discovery of grounded theory: Strategies for qualitative research. New York: Aldine Publishing Company.

Goddard, E. (2021). The impact of COVID-19 on food retail and food service in Canada: A second assessment. Canadian Journal of Agricultural Economics/Revue canadienne d'agroeconomie. Doi: doi.org/10.1111/cjag.12282

Gössling, S., Scott, D. ve Hall, C. M. (2020). Pandemics, tourism and global change: a rapid assessment of COVID-19. Journal of Sustainable Tourism, https://doi.org/10.1080/09669582.2020.1758708

Gursoy, D. ve Chi, C. G. (2020). Effects of COVID-19 pandemic on hospitality industry: review of the current situations and a research agenda. Journal of Hospitality Marketing \& Management, 29(5), 527-529.

Hao, F., Xiao, Q. ve Chon, K. (2020). COVID-19 and China's hotel industry: Impacts, a disaster management framework, and post-pandemic agenda. International Journal of Hospitality Management, 90, 102636.

Hobbs, J. E. (2020). Food supply chains during the COVID-19 pandemic. Canadian Journal of Agricultural Economics/Revue canadienne d'agroeconomie, 68(2), 171-176.

İbiş, S. (2020). Covıd-19 salgınının seyahat acentaları üzerine etkisi. Safran Kültür ve Turizm Araştırmaları Dergisi, 3(1), 85-98.

İşkur (2021). Kısa Çalışma Ödeneği. [URL: https://www.iskur.gov.tr/isveren/kisa-calismaodenegi/genel-bilgiler/] (Erişim Tarihi: 28 Mayıs 2021).

Kim, J. ve Lee, J. C. (2020). Effects of COVID-19 on preferences for private dining facilities in restaurants. Journal of Hospitality and Tourism Management, 45, 67-70.

Kim, J., Kim, J. ve Wang, Y. (2021). Uncertainty risks and strategic reaction of restaurant firms amid COVID-19: Evidence from China. International Journal of Hospitality Management, 92, 102752.

Kültür ve Turizm Bakanlığ1 (2021). Turizm Gelirleri ve Giderleri. [URL: https://yigm.ktb.gov.tr/TR-201116/turizm-gelirleri-ve-giderleri.html] (Erişim Tarihi: 27 Mayıs 2021).

Lai, I. K. W. ve Wong, J. W. C. (2020). Comparing crisis management practices in the hotel industry between initial and pandemic stages of COVID-19. International Journal of Contemporary Hospitality Management, 32(10), 3135-3156.

Luo, Y. ve Xu, X. (2021). Comparative study of deep learning models for analysing online restaurant reviews in the era of the COVID-19 pandemic. International Journal of Hospitality Management, 94, 102849. 
Lune, H. ve B. L. Berg (2004). Qualitative Research Methods for the Social Sciences. Boston, MA: Pearson.

Okat, Ç., Bahçeci, V. ve E. Ocak (2020) COVID-19 (Yeni Koronavirüs) salgınının neden olduğu krizin yiyecek içecek işletmeleri üzerindeki etkisinin değerlendirilmesi. Uluslararası Güncel Turizm Araştırmaları Dergisi, 4(2), 201-218.

Özgüneş, R. E., Bozok, D. ve Küçükaltan, D. (2020). Yiyecek ve içecek sektöründe ileri teknoloji ve pandemik düzene doğru: Yakın gelecekte bir robota 'Eline Sağlık!' diyebilir miyiz?. Afyon Kocatepe Üniversitesi Sosyal Bilimler Dergisi, 22(4), 1124-1139.

Panzone, L. A., Larcom, S. ve She, P. W. (2021). Estimating the impact of the COVID-19 shock on UK food retailers and the restaurant sector. Global Food Security, 100495.

Resmî Gazete (2020). Kısa Çalışma Ödeneğinin Uzatılması Konulu 3134 Sayılı Cumhurbaşkanı Kararı. [URL: https://www.resmigazete.gov.tr/eskiler/2020/10/20201027-1.pdf] (Erişim Tarihi: 28 Mayıs 2021).

Russell, R. ve Faulkner, B. (2004). Entrepreneurship, chaos and the tourism area lifecycle. Annals of Tourism Research, 31(3), 556-579.

Saunders, B., Sim, J., Kingstone, T., Baker, S., Waterfield, J., Bartlam, B., Burroughs H. ve Jinks, C. (2018). Saturation in qualitative research: exploring its conceptualization and operationalization. Quality \& Quantity, 52(4), 1893-1907.

Seyitoğlu, F. ve Ivanov, S. (2021). Service robots as a tool for physical distancing in tourism. Current Issues in Tourism, 24(12), 1631-1634.

Sung, Y. K. ve King, B. (2021). Restaurant preventive behaviors and the role of media during a pandemic. International Journal of Hospitality Management, 95,102906.

Van Manen, M. (2016). Phenomenology of practice: Meaning-giving methods in phenomenological research and writing. Routledge.

Van Manen, M., Higgins, I. ve van der Riet, P. (2016). A conversation with Max van Manen on phenomenology in its original sense. Nursing\&Health Science, Special Issue: Qualitative Research,18(1), 4-7.

Vo-Thanh, T., Vu, T. V., Nguyen, N. P., Nguyen, D. V., Zaman, M. ve Chi, H. (2021). COVID19, frontline hotel employees' perceived job insecurity and emotional exhaustion: Does trade union support matter?. Journal of Sustainable Tourism, Doi: 10.1080/09669582.2021.1910829

Wei, C. V., Chen, H. ve Lee, Y. M. (2021). Factors influencing customers' dine out intention during COVID-19 reopening period: The moderating role of country-oforigin effect. International Journal of Hospitality Management, 95, 102894.

Wilson, M. (2010). Developments in robot applications for food manufacturing. Industrial Robot: An International Journal, 37(6), 498-502.

Wong, A. K. F., Kim, S. S., Kim, J. ve Han, H. (2021). How the COVID-19 pandemic affected hotel employee stress: Employee perceptions of occupational stressors and their consequences. International Journal of Hospitality Management, 93, 102798. 
World Health Organization (2020). WHO Director-General's opening remarks at the media briefing on COVID-19 [URL: https://www.who.int/directorgeneral/speeches/detail/who-director-general-s-opening-remarks-at-the-mediabriefing-on-covid-19---11-march-2020 ] (Erişim Tarihi: 11 Mart 2021).

Yang, F. X., Li, X., Lau, V. M. C. ve Zhu, V. Z. (2021). To survive or to thrive? China's luxury hotel restaurants entering $\mathrm{O} 2 \mathrm{O}$ food delivery platforms amid the COVID-19 crisis. International Journal of Hospitality Management, 94, 102855.

Yost, E., ve Cheng, Y. (2021). Customers' risk perception and dine-out motivation during a pandemic: Insight for the restaurant industry. International Journal of Hospitality Management, 95, 102889.

Yost, E., Kizildag, M. ve Ridderstaat, J. (2021). Financial recovery strategies for restaurants during COVID-19: Evidence from the US restaurant industry. Journal of Hospitality and Tourism Management, 47, 408-412.

Zeng, Z., Chen, P. ve Lew, A. (2020). From high-touch to high-tech: COVID-19 drives robotics adoption. Tourism Geographies, 22(3), 724-734. 